Prima: Jurnal Pendidikan Matematika

Vol. 5, No. 1, January 2021, pp. 1-10

P-ISSN: 2579-9827, E-ISSN: 2580-2216

Web: http://jurnal.umt.ac.id/index.php/prima

\title{
DESIGN OF INTERACTIVE LEARNING MEDIA IN THE COVID-19 PANDEMIC TIME USING ISPRING
}

\author{
Ahmad Fadillah ${ }^{1}$, Westi Bilda ${ }^{2}$, Hairul Saleh ${ }^{3}$, Yenni $^{4}$ \\ Universitas Muhammadiyah Tangerang, Jl. Perintis Kemerdekaan I/33, Cikokol, Tangerang, Indonesia \\ e-mail: ahmadfadillah@umt.ac.id
}

\begin{abstract}
The learning process is a systematic activity deliberately designed by educators to achieve the desired learning objectives. One of the factors that affect the process of learning is a learning medium. Learning media is a tool that educators use to deliver the concept or material to target and meaningful learners. This research was conducted at Universitas Muhammadiyah Tangerang in the mathematics education study program. The purpose of this research is to develop Ispring interactive media design. The methods used in this study are research and development with ADDIE (Analysis, Design, Development, Implementation, Evaluation) models. The stages include analysis, design, development, and implementation. Based on the experts' validation results by getting scores of $80.34 \%$ and $80 \%$ respectively with proper criteria, and the results of small-scale trials got a score of $85 \%$ and $88.34 \%$, respectively, which was feasible and usable.
\end{abstract}

Keywords: Covid-19, Ispring, Interactive Media

\begin{abstract}
Abstrak
Proses pembelajaran merupakan kegiatan yang sistematis yang sengaja dirancang oleh pendidik agar tujuan pembelajaran yang inginkan tercapai. Salah satu faktor yang mempengaruhi proses pembelajaran adalah media pembelajaran. Media pembelajaran merupakan alat bantu yang digunakan oleh pendidik agar konsep atau materi yang akan disampaikan tepat sasaran dan bermakna bagi peserta didik. Penelitian ini dilakukan di Universitas Muhammadiyah Tangerang pada program studi Pendidikan Matematika. Tujuan dari penelitian ini adalah menghasilkan produk media interaktif Ispring. Metode yang digunakan dalam penelitian ini adalah penelitian dan pengembangan (Research and Development) dengan model ADDIE (Analysis, Design, Development, Implementation, Evaluation). Tahapan yang dilakukan adalah meliputi analisis, desain, pengembangan, dan implementasi. berdasarkan hasil validasi para ahli dengan mendapatkan skor masingmasing $80,34 \%$ dan $80 \%$ dengan kriteria layak, dan hasil dari ujicoba skala kecil mendapatkan skor masingmasing $85 \%$ dan $88,34 \%$ dengan layak dan bisa digunakan.
\end{abstract}

Kata kunci: Covid-19, Ispring, Media Interaktif

INTRODUCTION

Coronavirus disease 2019 (Covid-19), which has hit countries globally, has its impact and challenges for educational institutions, especially universities. To prevent the wider spread of Covid-19, the Government has banned mass crowding, social distancing, and physical distancing. Through the Ministry of Education and Culture, the Government of Indonesia has prohibited universities from conducting face-to-face (conventional) lectures for an unspecified amount of time and replacing them with online lectures. Moore et al., (2011) Online learning is a learning that uses the internet network with accessibility, connectivity, flexibility, and the ability to bring forth different types of learning interactions. 
Various media can also be used to support the implementation of online learning. For example, virtual classes use Google Classroom, Edmodo, and Schoology services (Enriquez, 2014; Sicat, 2015; Shampa, 2016) and instant messaging apps like WhatsApp (So, 2016). Online learning can even be done through social media such as Facebook and Instagram (Kumar \& Nanda, 2018). Learning Media is every person, material, tool, or event that can create conditions that allow learners to receive knowledge, skills and attitudes (Purwono, 2018). Media is a tool to deliver messages or learning information that will be conveyed by the message source to the recipient of the message (Umar, 2014). Smaky says learning media is a tool that works and is used to convey the message of learning (Suryani et al., 2018). Learning media works and can be used to convey messages when learning. Besides, the use of learning media in the learning process can awaken new desires and interests, generate motivation and stimulation of learning, and even bring psychological influences to students (As-Syifa, 2018). Based on some of the above understandings, learning media is a tool used to convey the message of learning delivered by the message source to the recipient of the message.

Some of the subjects that need to be supported with interactive multimedia programs. One of them is mathematics. Because mathematics is a lesson that does not rely on memory skills. However, students are required to understand the material in order to determine the solution of a given problem (Waldopo, 2011). A wide range of applications and software can be used as a learning medium. One of them is Ispring. Himmah (2017) Ispring is a software that can convert presentation files to flash format so that other programmers cannot edit it. So that each product produced has its characteristics. Teachers or lecturers can use Ispring as an alternative if the school does not have a projector, the teacher can transfer it into a CD or DVD as a provision for students in-home learning (Kartono, 2014).

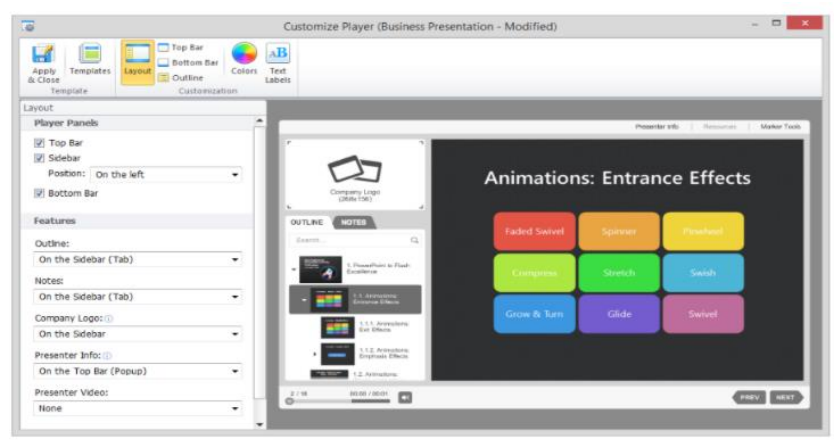

Figure 1. Ispring Media Layout View 
This software can also be used to add quizzes, add audio, video recorders. So using Ispring can make presentation files more interesting. Wagino, et al., (2015) states that this software can also convert presenter files to scorm/AICC form, which is a form that can be used in LMS (Learning Management System) e-learning. This function makes it easier for users, so that users can utilize Ispring as a tool for online learning activities. Basuki dan Sholeh (2014) Ispring works as a PowerPoint add-in, to make PowerPoint files more attractive and interactive flash-based and easily opened on any computer or platform, easily distributed in a flash format which can be used and optimized for the web.

Some of the previous research related to iSpring interactive media include: Anwar et al., (2019) learning based on iSpring successfully increases students' learning interests; Amali et al., (2019) the use of iSpring makes the learning process more interactive; Handayani \& Awaludin (2020) Ispring increases students retention on calculus concept II. The latest research was conducted during the Covid-19 pandemic in the course of flat analytical geometry. Based on the above assumptions, it is necessary to design interactive learning media to optimize flat analytical geometry's learning activities. Thus, the formulation of the problems raised in this study is how the development and quality of Ispring interactive media is?

\section{METHODS}

This research is based on $R$ \& D research with models used by ADDIE (Analysis, Design, Development, Implementation, Evaluation ). Sugiyono (2016) R \& D is a research method used to produce a particular product and test its effectiveness. Suryani, et al. (2018) stated that the ADDIE model focuses on developing learning goals, and one of them is media. This model's advantage is its work step, which refers to the previous work step that has been improved, so it is expected to get an effective product. The stages performed by researchers this time include analysis, design, development, and implementation. This iSpring based interactive media development uses second-half flat analytical geometry materials. Ispring's interactive media helps the learning process be more concrete with videos, audios, materials, animations, and images. 


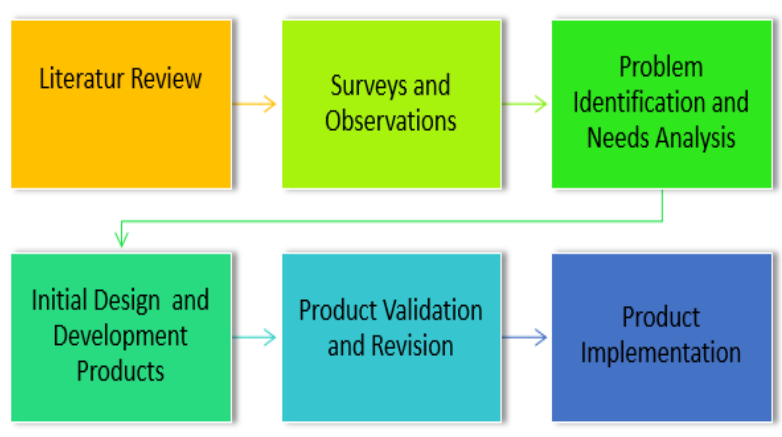

Figure 2. ADDIE Model Research Roadmap

The quality of resulting product is analyzed with the measures adopted from the Fadillah dan Bilda (2019). Polls used for validity assessments using numerical ranking scales adapted from Sugiyono (2016). To measure the product's practicality is analyzed with the measures and practicality criteria adopted from (Setiawan, 2017).

\section{RESULTS AND DISCUSSION}

The result of this study is a product of valid, practical, and effective Ispring interactive media that students can use in understanding flat analytical geometry materials. This research goes through several steps as follows: Analysis stage, researchers perform analysis of the need to produce learning media that match students' needs in flat analytical geometry courses. At the time of initial observation, researchers saw that students were less interested and enthused following lectures. Lecturers still looked dominant so that students were less actively involved, and it has not seen any use of learning media according to students' needs and conditions. So this is the focus of researchers to develop learning media.

The design stage, the result of the needs analysis, is arranged and processed into a design that will be used as a reference for the manufacture of the initial product. The next stage is to design learning media according to basic competencies and learning achievements. At this stage, researchers design learning media by considering the feasibility of the content or material, language, and presentation. Besides, researchers also take to the principles in mathematics, as developed media can foster interest and curiosity, and imagination in the process of learning activities. The original product has been created, then validated, and inputted by materials experts and media experts. Validation results can be used as a reference for improvement in order for the product to fit the original purpose. Here are the validation results of material experts and media experts with indicators adapted from (Fadillah \& Bilda, 2019), namely: content eligibility, language, and presentation. 
Table 1. Material Expert and Media Expert Validation Results

\begin{tabular}{clcc}
\hline No. & \multicolumn{1}{c}{ Indicator } & \multicolumn{2}{c}{ Persentase (\%) } \\
& & Material Expert & Media Expert \\
\hline $\mathbf{1}$ & content eligibility & 78 & 80 \\
$\mathbf{2}$ & Language & 80 & 75 \\
$\mathbf{3}$ & Presentation & 83 & 80 \\
& & & 80 \\
& Average & 80.34 & Good \\
\hline
\end{tabular}

Based on the table above, the results for material experts and media experts are $80.34 \%$ and $80 \%$ in good criteria so that it is worth using.

The development and Implementation stages. At this stage, the manufacture of products that have been processed at the design stage. The creation of existing components of learning media is done with iSpring. Furthermore, the product is tested in the field on a small scale. The trial results were catalyzed to determine whether or not the product should proceed to the next stage of implementation. This stage is at the stage of applying the results of products that have been made and tested to experts. Learning media products are said to be feasible by experts, so they are then tested to assess the practicality of the product. The questionnaire results will be used as a reference to revise the product until the product is completely practical to use.

Table 2. Small Scale Test Results

\begin{tabular}{clcc}
\hline No. & Indicator & \multicolumn{2}{c}{ Percentage (\%) } \\
& & Lecturer & Students \\
\hline $\mathbf{1}$ & content eligibility & 83 & 90 \\
$\mathbf{2}$ & Language & 85 & 85 \\
$\mathbf{3}$ & Presentation & 87 & 90 \\
& & & \\
& Average & 85 & 88.34 \\
& Criteria & Very decent & Very decent \\
\hline
\end{tabular}

Based on the table above, lecturers' assessment gets a percentage of $85 \%$ with criteria very feasible so that media can be implemented to students. Implementation to students is done to know the students' responses when doing learning using iSpring based interactive media. The students' responses received a percentage of $88.34 \%$ of the category is very feasible, so the media is said to be practical in its use.

In this study, researchers conducted observations and analysis by conducting field studies and identification to determine the problems and obstacles in the study of Analytical Geometry courses, conducting needs assessment analysis. Furthermore, formulating 
materials and media that are assai and suitable with the conditions in the field to be applied to students of the mathematics education study program Universitas Muhammadiyah Tangerang.

After formulating the material and media, the second stage is creating the design, as the media that wants to be created is iSpring interactive media. The design stage that researchers are doing is creating a material design that supports being created on Microsoft PowerPoint worksheets, images, videos, animations, sound effects, questions, and answer keys. Products that have been created, validated and input by material experts and media experts. The validation results of material experts and media experts show the criteria are worth using. This is seen in table 1 . There is a minor revision in the form of color selection that is too conspicuous for media experts so that it does not look attractive. This corresponds to Thabroni (2018) select the dominant main color and matches it with the relevant harmonious color. Keep an eye on how each color affects human psychology. For example, if the main color is red, don't use too much. Red is a strong color and should be balanced by a softer color.

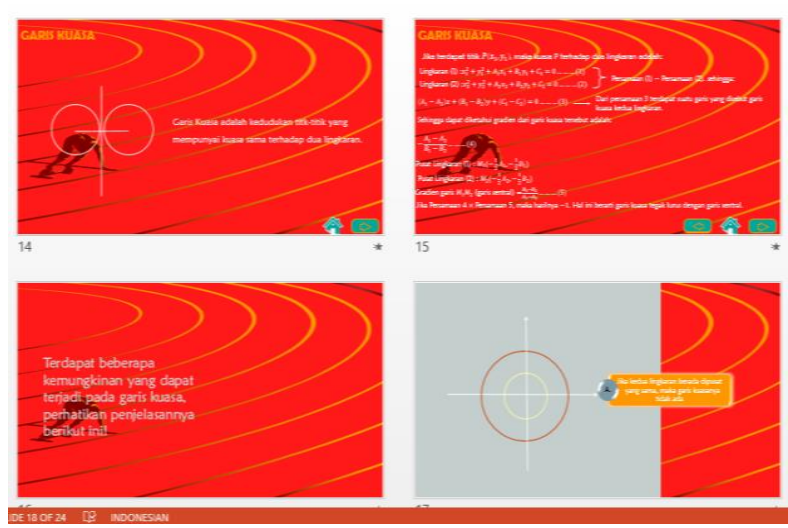

Figure 3. Before revised 


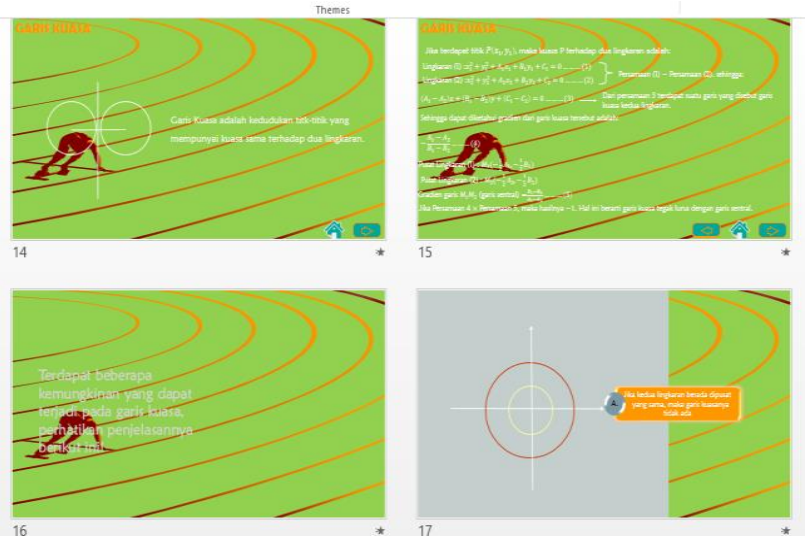

Figure 4. Revised

After revision and improvement, then continued at the small-scale test stage to know the product's practicality to lecturers and students, and obtained very practical results and worth using. It is seen in Table 2. From the various stages and analysis that has been done, the purpose of this research is said to have been achieved and obtained results in the form of products that have qualified validity and practicality, it in accordance with the opinion (Disnawati \& Nahak, 2019).

Ispring media is expected to help in the learning process more interesting and can improve students learning achievement. By the use of learning media can improve the learning experience and self-reliance while following the learning process. Hamalik stated that learning media could generate new desires and interests, generate motivation and stimulation of learning activities, and bring psychological influence to students (Hastuti et al., 2017). The use of learning media can clarify the presentation of messages and information so as to facilitate and improve the learning process and results (Samura, 2015). The use of learning media by utilizing technology can improve the results of learning mathematics. Learning mathematics with learning media that use ICT is better than the results of learning mathematics using conventional media. Average math scoring using ICT media was 79 while using conventional media was 72.75 (Tatan \& Sumiati, 2011).

\section{CONCLUSION}

Based on the formulation of the problems and the results of the study described above, the researchers concluded that this study produced iSpring interactive media products as one of the alternatives of online learning media during the covid-19 pandemic that is worth using based on the validation results of experts with criteria worth using. And based on the 
assessment of lecturers and students by obtaining criteria is very feasible. This media contains material supported by images, videos, animations, quizzes, and answer keys to help students learn independently.

Regardless of the results of the above study, researchers recommend that more indepth research be done to improve the produced products. Researchers realize that there are still so many shortcomings during the study from start to finish and can be used as a reference in developing other learning media.

\section{ACKNOWLEDGMENTS}

We appreciate all those who have helped in this research, especially to the National Innovation Research Agency (BRIN), which has funded this research, and colleagues of the mathematics education study program of Universitas Muhammadiyah Tangerang.

\section{REFERENCES}

Amali, L. N., Kadir, N. T., \& Latief, M. (2019). Development of e-learning content with H5P and iSpring features. Journal of Physics: Conference Series. https://doi.org/10.1088/1742$6596 / 1387 / 1 / 012019$

Anwar, M. S., Choirudin, C., Ningsih, E. F., Dewi, T., \& Maseleno, A. (2019). Developing an Interactive Mathematics Multimedia Learning Based on Ispring Presenter in Increasing Students' Interest in Learning Mathematics. Al-Jabar : Jurnal Pendidikan Matematika. https://doi.org/10.24042/ajpm.v10i1.4445

As-Syifa, D. (2018). Media Pembelajaran. Jakarta: Rajagrafindo Persada. https://doi.org/10.31227/osf.io/34rhg

Basuki, Untung Joko \& Sholeh, M. (2014). Pemanfaatan Sumber Belajar Berbasis Teknologi Informasi Pada Pembelajaran Pendidikan Agama Islam Dengan Menggunakan Ispring $\begin{array}{llll}\text { Presenter. Jurnal Gaung Infornatika, } & \text { 103-112. }\end{array}$ http://jurnal.usahidsolo.ac.id/index.php/Gl/article/view/232/189

Disnawati, H., \& Nahak, S. (2019). Pengembangan Lembar Kerja Siswa Berbasis Etnomatematika Tenun Timor pada Materi Pola Bilangan. Jurnal Elemen. https://doi.org/10.29408/jel.v5i1.1022

Enriquez, M. A. S. (2014). Students ' Perceptions on the Effectiveness of the Use of Edmodo as a Supplementary Tool for Learning. DLSU Research Congress. 
https://doi.org/10.1017/CBO9781107415324.004

Fadillah, Ahmad \& Bilda, W. (2019). Pengembangan Video Pembelajaran Berbantuan Aplikasi Sparkoll Videoscribe. Jurnal Gantang. https://doi.org/10.31629/jg.v4i2.1369

Handayani, S. D., \& Awaludin, A. A. R. (2020). Pengembangan Media Pembelajaran Interaktif Berbantu Software iSpring terhadap Retensi Mahasiswa pada Konsep Kalkulus II. ARITHMETIC: Academic Journal of Math. https://doi.org/10.29240/ja.v2i1.1506

Hastuti, N. L., Waryanto, N. H., \& Retnowati, E. (2017). Pengembangan Media Pembelajaran Matematika Berbasis Edutainment Berupa Android Mobile Game Untuk Siswa SMP Kelas VII Pada Materi Segi Empat. Pengembangan Media Pembelajaran.

HIMMAH, F. (2017). Pengembangan Multimedia Interaktifm Menggunakan Ispring Suite 8 Pada Sub Materi Zat Aditif untuk Meningkatkan Hasil Belajar Siswa SMP Kelas VIII. $\begin{array}{lllll}\text { PENSA } & E \text { JURNAL: PENDIDIKAN }\end{array}$ https://jurnalmahasiswa.unesa.ac.id/index.php/pensa/article/view/18834

Kartono. (2014). No Title. Pemanfaatan Ms. Powerpoint Dan Ispring Dalam Pembelajaran Matematika Berbasis Technological Pedagogigal Content Knowledge (Tpack) Sebagai Upaya Optimalisasi Implementasi Kurikulum 2013, 427-444. https://www.researchgate.net/publication/320842863

Kumar, V., \& Nanda, P. (2018). Social Media in Higher Education. International Journal of Information and Communication Technology Education. https://doi.org/10.4018/ijicte.2019010107

Moore, J., Dickson-Deane, C., \& Galyen, K. (2011). E-learning, online learning, and distance learning. Internet and Higher Education.

Purwono, J. dkk. (2018). Penggunaan Media Audio-Visual Pada Mata Pelajaran IImu Pengetahuan Alam Di Sekolah Menengah Pertama Negeri 1 Pacitan. Jurnal Teknologi Pendidikan Dan Pembelajaran.

Samura, A. O. (2015). Penggunaan media dalam pembelajaran matematika dan manfaatnya. Delta-Pi: Jurnal Matematika Dan Pendidikan Matematika.

Setiawan, H. (2017). Pengembangan Media Interaktif Adobe Flash dengan pendekaran matematika realistik pada bangun ruang sisi datar.

Shampa, I. (2016). Google classroom: What works and how? Journal of Education and Social Sciences. 
Sicat, A. S. (2015). Enhancing College Students' Proficiency in Business Writing Via Schoology. International Journal of Education and Research.

So, S. (2016). Mobile instant messaging support for teaching and learning in higher education. Internet and Higher Education. https://doi.org/10.1016/j.iheduc.2016.06.001

Sugiyono. (2016). Metode Penelitian Kuantitatif Kualitataif dan Kombinasi (Mixed Methods). Journal of Chemical Information and Modeling.

Suryani, Nunuk. Setiawan, Achmad. Putria, A. (2018). Media pembelajaran inovatif dan pengembangannya. Bandung: PT Remaja Rosdakarya.

Thabroni, G. (2018). Perpaduan Warna Harmonis menggunakan Teori Warna \& Seni.

Umar. (2014). Media Pendidikan: Peran dan Fungsinya dalam Pembelajaran. Jurnal Tarbiyah.

Wagino, Nur Alamsyah, \&, \& Zaenuddin. (2015). Pembuatan Media Pembelajaran Interaktif Dengan Perangkat Lunak Ispring Presenter Di SMAN 4 Banjarmasin. Jurnal Pengabdian Al-Ikhlas Universitas Islam Kalimantan Muhammad Arsyad Al Banjary, 1(1), 19-22. https://doi.org/http://dx.doi.org/10.31602/jpai.v1i1.297

Waldopo. (2011). Analisis Kebutuhan terhadap Program Multi Media Interaktif sebagai Media Pembelajaran. Urnal Pendidikan Dan Kebudayaan, 17(2), 244-253. https://doi.org/10.24832/jpnk.v17i2.21

Zenal Mutakin , Tatan \& Sumiati, T. (2011). Pengaruh Penggunaan Media Belajar Dan Minat Belajar Terhadap Hasil Belajar Matematika (Eksperimen Pada Siswa Kelas XI IPA Sma Negeri 8 Kota Tangerang Selatan Tahun Pelajaran 2010 / 2011). Jurnal Formatif, 1, 7081. https://doi.org/http://dx.doi.org/10.30998/formatif.v1i1.64 